\title{
Herbivory affects ovarian development in the zoophytophagous predator Brontocoris tabidus (Heteroptera, Pentatomidae)
}

\author{
W. P. Lemos · J. C. Zanuncio · F. S. Ramalho • \\ V. V. Zanuncio $\cdot$ J. E. Serrão
}

Received: 2 December 2008/Accepted: 3 August 2009/Published online: 28 August 2009

(C) Springer-Verlag 2009

\begin{abstract}
The effect of prey-based and combination prey and plant-based diets [Tenebrio molitor pupae alone; $T$. molitor pupae and Eucalyptus cloeziana plants; T. molitor pupae and Eucalyptus urophylla plants; and T. molitor pupae and Psidium guajava (guava) plants] on the morphometry of the ovary of Brontocoris tabidus (Signoret) (Heteroptera: Pentatomidae) was analyzed in the field. Females fed on T. molitor pupae without plants presented with smaller ovarioles. The number of oocytes per ovary was higher for B. tabidus females fed on a combination diet of E. urophylla and T. molitor pupae when compared to females fed only on prey. In addition to diet, the number of oocytes in the ovariole was shown to vary with the age of B. tabidus. The 21-day-old B. tabidus females were found to have a higher number of oocytes per ovariole than the
\end{abstract}

Communicated by N. Agusti.

W. P. Lemos $\cdot$ J. C. Zanuncio

Departamento de Biologia Animal, Universidade Federal de

Viçosa, Vicosa, Minas Gerais 36570-000, Brazil

W. P. Lemos

Laboratório de Entomologia, Embrapa Amazônia Oriental,

Caixa Postal 048, Belém, Pará 66095-100, Brazil

F. S. Ramalho

Unidade de Controle Biológico (UCB), Embrapa Algodão, Caixa

Postal 147, Campina Grande, Paraíba 58107-720, Brazil

V. V. Zanuncio

Faculdade de Medicina, Universidade Federal de Juiz de Fora, Juiz de Fora, Minas Gerais 36036-330, Brazil

J. E. Serrão $(\bowtie)$

Departamento de Biologia Geral, Universidade Federal de

Viçosa, Vicosa, Minas Gerais 36570-000, Brazil

e-mail: jeserrao@ufv.br 15-day-old females in all diet conditions. The 15-day-old females exhibited more developed oocytes when fed on diets containing both prey and eucalypts plants and less developed oocytes when fed with a combination diet containing guava plants or T. molitor pupae alone. The 21-oneday-old $B$. tabidus females which were fed with a diet without plants had smaller oocytes than those fed with plants. Herbivory improves the morphology of the ovary of B. tabidus, affecting the size of the reproductive structures and the oogenesis of this natural enemy in the field.

Keywords Asopinae - Biological control .

Morphometry · Ovary $\cdot$ Omnivory

\section{Introduction}

Asopinae predators are natural enemies with potential to be used in integrated pest management programs (Coll and Ruberson 1998). These natural predators may be useful in the biological control agent against defoliator insects in different ecosystems. The study of Brontocoris tabidus (Signoret) (Heteroptera: Pentatomidae) in Brazil was started about 10 years ago, despite the fact that this asopine has high potential for use in pest control, particularly in reforested areas (Zanuncio et al. 1994; Jusselino Filho et al. 2003). The potential uses of this natural predator have led to multiple studies to understand its growth and development, including the use of artificial diets (Zanuncio et al. 1996, 2006) and supplementary feeding on plants (Zanuncio et al. 2000).

Inadequate diets may affect the ecology, behavior, and evolutionary diversification of a species, which can hinder the manipulation and use of insect predators in integrated pest management (Obrycki et al. 2004). Predatory insects, 
even those that are omnivorous, have been recognized for their use in the biological control of insect pests in several systems (Armer et al. 1998; Eubanks and Denno 1999; Gillespie and McGregor 2000; Lemos et al. 2001; Symondson et al. 2002; Sinia et al. 2004; Zanuncio et al. 2004).

The internal morphology of the reproductive system of Heteroptera has been described (Matsuda 1976), and more specifically, Adams (2001) described the reproductive system of an asopine [Perillus bioculatus (F.)]. Insects generally have ovaries with a relatively constant number of ovarioles (Simiczyjew et al. 1998; Martins and Serrão 2004), and are often species or family specific, usually numbering from four to seven per ovary (Büning 1994; Lisboa et al. 2005).

The impact of different diets on the development of the reproductive structures of Asopinae, including B. tabidus, is poorly understood (Adams 2001; Wittmeyer et al. 2001; Lemos et al. 2003, 2005a). However, understanding the effects of diet is highly important, as different diets may influence reproduction through effects on the development of the ovaries. This knowledge may facilitate the use of $B$. tabidus for pest control, as well as contribute to our understanding of its nutritional ecology. Therefore, in order to test the hypothesis that more appropriate diets promote development of the reproductive structures in B. tabidus females, specimens were reared in the field on different diets (with or without plants), and the resulting morphometry of the ovarioles of the 15- and 21-day-old $B$. tabidus were compared.

\section{Materials and methods}

\section{Animals}

Field studies were conducted near the Department of Animal Biology and in the Biological Control of Insects of the Institute of Applied Biotechnology to Agriculture (BIOAGRO) laboratory and in the Molecular and Cell Biology and Reproductive Histology laboratories, Department of General Biology of the Federal University of Viçosa (UFV), in Viçosa, State of Minas Gerais, Brazil.

Specimens of $B$. tabidus were obtained from colonies maintained by the laboratory of Biological Control of Insects of the UFV. Initial colonies were reared in woodenscreened cages $(30 \times 30 \times 30 \mathrm{~cm})$ with a glass container containing water and Eucalyptus urophylla leaves as vegetable substratum for feeding. Tenebrio molitor pupae were supplied from the mass rearing facility at the same laboratory. Twenty pairs of newly emerged adult $B$. tabidus insects were mated per treatment in the laboratory to obtain the progeny used in the study.
Diets

Nymphs and adults of B. tabidus were maintained in the field with or without plants in cloth bags $(70 \mathrm{~cm} \times 40 \mathrm{~cm})$ (Zanuncio et al. 2004) (Fig. 1a-c). The treatments included: T. molitor pupae without plants $\left(\mathrm{T}_{1}\right), T$. molitor pupae and Eucalyptus cloeziana plants $\left(\mathrm{T}_{2}\right) ; T$. molitor pupae and Eucalyptus urophylla plants $\left(\mathrm{T}_{3}\right)$; and T. molitor pupae and Psidium guajava (guava) plants $\left(\mathrm{T}_{4}\right)$.

Five hundred nymphs of $B$. tabidus were fed on each diet. These nymphs were obtained from the 20 pairs of laboratory insects as described above. Nymphs were kept in cloth bags through the adult stage. Tenebrio molitor pupae were supplied ad libitum and changed with the water twice a week. A total of 900 individuals were used in $\mathrm{T}_{1}$ diet condition due to the high mortality of B. tabidus nymphs caused by absence of plant in this treatment.
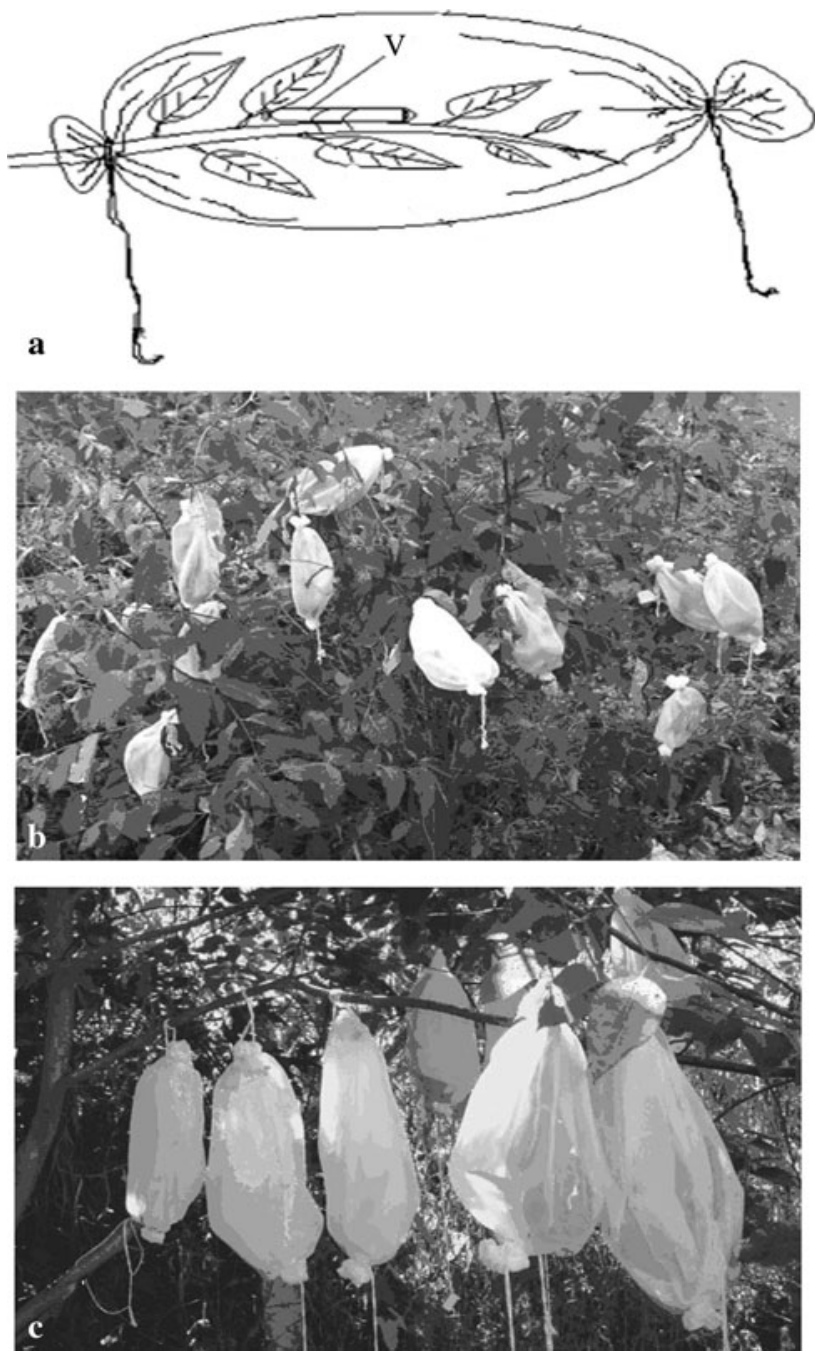

Fig. 1 White tissue bags used in the field to rear B. tabidus in plants (a). Details of the bags covering (b) and not covering (c) branches of plants. $V$ vial to supply water 
Brontocoris tabidus adults were sexed upon the first day after molting to the adult stage, based on the external appearance of their genitalia; they were allowed to mate. Thirty-six pairs were utilized for each treatment, with the exception of $T_{1}$. The $T_{1}$ condition required the use of 50 pairs of insects due to the high mortality in this treatment. Brontocoris tabidus adults received the same diet as they had as nymphs. The pairs were maintained in cloth bags $(25 \mathrm{~cm} \times 15 \mathrm{~cm})$ covering branches of plants; they were provided water supplied by $2.5-\mathrm{ml}$ cylindrical tubes (Zanuncio et al. 2004). Tenebrio molitor pupae were supplied ad libitum and changed twice a week with the water. Cloth bags containing predators in the $\mathrm{T}_{1}$ condition were maintained in the plants but not covering their branches. Males from the same treatment type were substituted for those which died before their respective females. The entire pair was replaced if the female died before the evaluation date. The number of dead individuals was registered every $48 \mathrm{~h}$.

\section{Morphometry}

Within each treatment, 10 females were transferred to Zamboni's fixative (Stefanini et al. 1967) at 15 and 21 days postmolting to adult stage. The ovaries were dissected and stored in the same fixative at room temperature.

The lengths of the ovarioles, the length of the most developed oocyte per ovary, the number of oocytes per most developed ovariole, and the number of oocytes per ovary were all calculated using Image Pro-Plus, version 4.5.1.29 (Media Cybernetics).

\section{Statistics}

Data sets were submitted to variance analysis, and means between treatments were compared using the NewmanKeuls test $(P=0.05)$. Means between ages in the same treatment were compared using the " $t$ " test $(P=0.05)$.

\section{Results}

Mated B. tabidus females were found to have clear or intense yellowish ovaries with seven ovarioles per ovary, two lateral oviducts, a common oviduct, accessory glands, and a vagina (Fig. 2a-c). The terminal filaments join the ovarioles, forming a compact bunch-shaped structure. In general, the ovarioles are long tubes surrounded by a welldeveloped tracheal net. The ovarioles of each ovary fused at the proximal end to form the lateral oviduct, characterized by having a larger diameter than the ovariole. The lateral oviducts combine to form a common oviduct with a diameter similar to that of the lateral oviducts.
Different diets did not affect the ovariole number per $B$. tabidus ovary, but they altered ovarian development (Fig. 2a-h). Brontocoris tabidus females fed on prey and plants (E. cloeziana, E. urophylla, or guava plant) had larger ovaries and ovarioles containing a high number of oocytes in advanced developmental stages (Fig. 2c-h). Histological analyses showed that those structures represented the eggshell and micropyle prolongations in ovaries from all ages and diets (not shown). Females fed on prey and plants had mature and well-developed oocytes along the entire extension of the ovariole; however, mature oocytes were more frequently found in the calyx, close to the lateral oviduct (Fig. 2d). Some B. tabidus females fed only on $T$. molitor pupae also had well-developed ovaries, but to a smaller degree than those fed on prey and plants (Fig. 2a, b).

The length of the most developed ovariole was not affected by the interaction diet $x$ age $x$ side of the body $(F=0.27$; df $=3,144 ; P>0.05)$; however, this parameter was affected by the diet type $(F=7.38$; df $=3,144$; $P<0.01)$. Females fed on $T$. molitor pupae without vegetable material had shorter ovarioles $(6.58 \pm 0.12 \mathrm{~mm})$ (Fig. 3). Females fed on plant and T. molitor pupae possessed the most developed ovarioles with average lengths of $7.54 \pm 0.22 ; 7.76 \pm 0.34$, and $8.13 \pm 0.22 \mathrm{~mm}$ long for E. cloeziana, guava, and E. urophylla plants, respectively (Fig. 3).

The number of oocytes per ovary $(F=1.20$; df $=3,72$; $P=0.31)$ and per most developed ovariole $(F=1.31$; df $=3,144 ; P=0.27$ ) of $B$. tabidus did not depend upon the interaction between diet $x$ age of the predator. However, the number of oocytes per ovary of $B$. tabidus was affected by diet $(F=4.05 ; \quad$ df $=3,70 ; \quad P<0.01)$ (Fig. 4a). Independent of the age of the predator, the number of oocytes was the highest in females fed on prey plus E. urophylla (45.00 \pm 2.77 oocytes) and the lowest in those fed on $T$. molitor pupae without plants $(28.50 \pm 2.86$ oocytes). Brontocoris tabidus females fed on prey combined with E. cloeziana or guava plants exhibited intermediate values for these parameters (Fig. 4a).

The diet $(F=4.14 ;$ df $=3,144 ; P<0.01)$ and age ( $F=4.25 ; \mathrm{df}=1,144 ; P=0.04)$, considered separately, also affected the number of oocytes per most developed ovariole. Brontocoris tabidus females fed on combination diets containing E. urophylla and guava plants had ovarioles that contained a higher number of oocytes than predators fed only on $T$. molitor pupae, and the difference was 1.32 fold (Fig. 4b). The 21-day-old B. tabidus females had a higher number of oocytes per ovariole $(5.13 \pm 019$ oocytes) than the 15 -day-old females (4.54 \pm 021 oocytes) (Fig. 5).

The length of the most developed B. tabidus oocyte was affected by the interaction diet $x$ age $(F=3.52$; df $=3$, 
Fig. 2 Inner genitalia of Brontocoris tabidus (Heteroptera: Pentatomidae) females fed on different diets. a b Poorly developed ovaries of 15-day-old females fed only on Tenebrio molitor pupae. c, $\mathbf{d}$ Ovaries of 15-day-old females fed on prey and plants of $E$. cloeziana and E. urophylla, respectively. e Ovariole with oocytes in different development degrees. $\mathbf{f}-\mathbf{h}$ Ovaries of B. tabidus fed on prey and E. urophylla (21 days old, F) and guava plant (15 days old, $\mathrm{G}$ and 21 days old, H). C calyx, $L O$ lateral oviduct, $O O$ oocyte, $O V$ ovariole, $T F$ terminal filaments.

Bars $=1.0 \mathrm{~mm}$
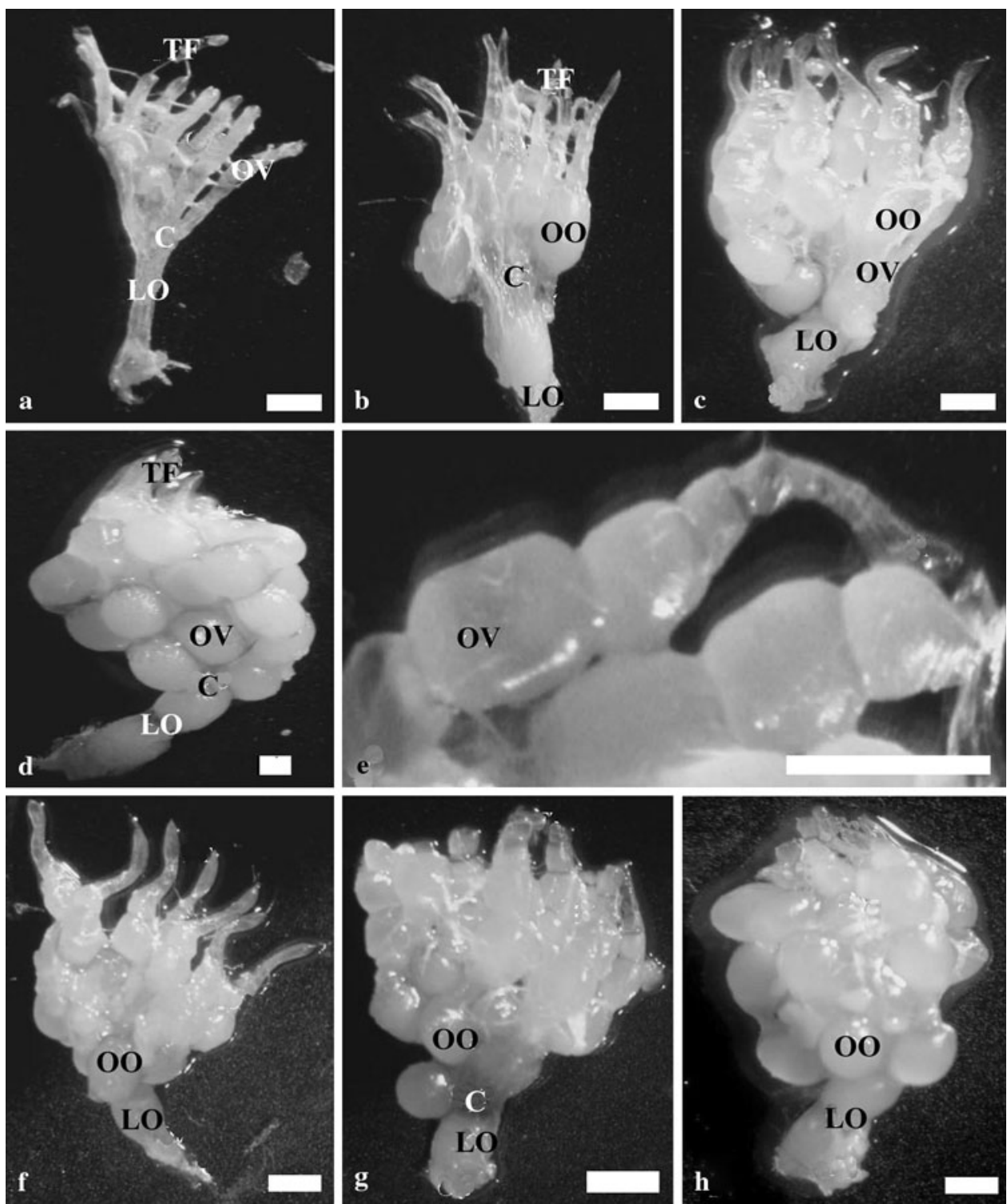

$128 ; P=0.02)$. The 15 -day-old females had better developed oocytes when fed on prey and E. cloeziana $(1.58 \pm 0.02 \mathrm{~mm})$ or $E$. urophylla $(1.62 \pm 0.05 \mathrm{~mm})$ than when fed on prey and guava plants $(1.35 \pm 0.10 \mathrm{~mm})$ or $T$. molitor pupae alone $(1.23 \pm 0.09 \mathrm{~mm})$ (Fig. 6). The 21-day-old $B$. tabidus females had smaller oocytes when fed a diet-lacking plants compared to diets containing E. cloeziana, E. urophylla, or guava plants (Fig. 6). Different plant-containing diets had no effect on the length of the oocyte at this age of this predator (Fig. 6).

The 21-day-old B. tabidus females fed on prey and guava plants $(1.61 \pm 0.03 \mathrm{~mm})$ or fed only on $T$. molitor pupae $(1.41 \pm 0.02 \mathrm{~mm})$ had more developed oocytes than the 15-day-old females with values of $1.35 \pm 0.10$ and $1.23 \pm 0.09 \mathrm{~mm}$, respectively (Fig. 6).

\section{Discussion}

The characterization, location, and color of the inner genitalia of B. tabidus females were similar to that described for other species of Heteroptera predators (Adams 2000, 2001; Wittmeyer et al. 2001; Lemos et al. 2005a).

Brontocoris tabidus females had seven ovarioles per ovary, independent of the diet and age, a characteristic that seems to be common for Pentatomidae. Seven ovarioles per ovary have also been reported for predatory species of this family including Perillus bioculatus (Adams 2000, 2001), Podisus maculiventris Say (Wittmeyer et al. 2001), and $P$. nigrispinus (Lemos et al. 2005a).

The structure of the ovaries of B. tabidus is similar to other Heteroptera predators. However, ovarian development was 


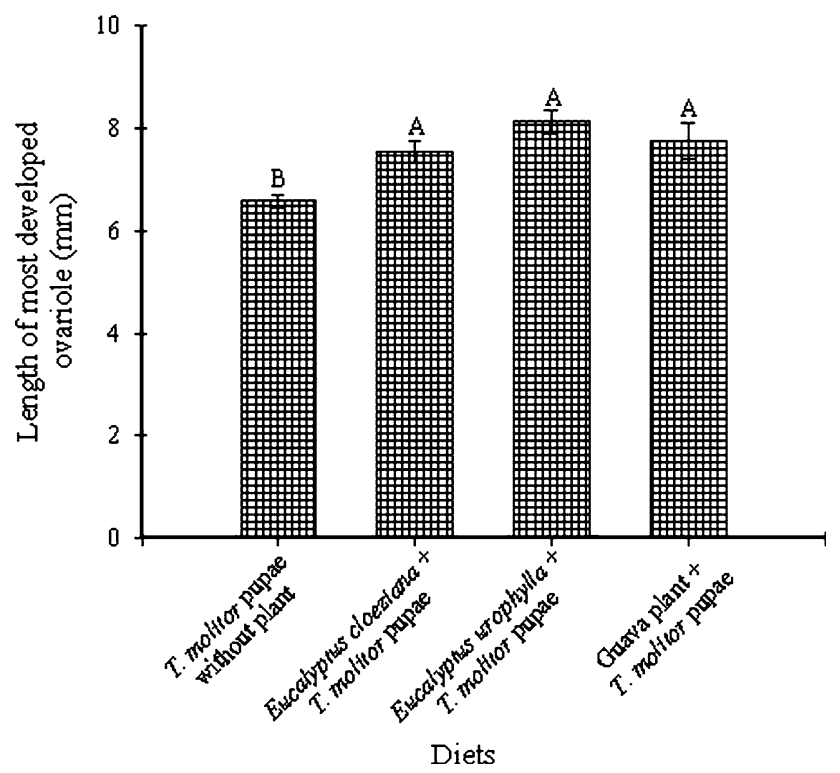

Fig. 3 Length of the most developed ovariole of Brontocoris tabidus (Heteroptera: Pentatomidae) female reared in the field. Columns followed by same letter do not differ for the test of Newman-Keuls $(P=0.05)$ affected by diet, similar to $P$. nigrispinus fed on different diets (Lemos et al. 2005a). Brontocoris tabidus females exhibited more developed ovaries when fed on diets containing both prey and plants. Higher ovarian development, may result in better reproductive fitness of the predator, as observed for females of $P$. nigrispinus. These predators were found to have more developed ovaries and high fecundity when fed on caterpillars of Alabama argillacea (Hübner) (Lepidoptera: Noctuidae) (Lemos et al. 2005a). The diet consumed by $P$. maculiventris nymphs has been shown to affect their ovarian development, primarily in the formation of previtellogenic follicles (Wittmeyer et al. 2001). Alterations in the diet of adults had more impact during vitellogenesis, while general reproductive aspects (fecundity and progeny survival) were affected by the diet used during the immature and adult stages (Wittmeyer et al. 2001). However, studies focused on the anatomy of the inner genitalia of Pentatomidae predators (Adams 2000, 2001; Wittmeyer et al. 2001; Lemos et al. 2005a, b), particularly on the effect of different diets on these structures (Lemos et al. 2005a, b), are both scarce and recent. Therefore, it is necessary to improve our understanding of the relationship between
Fig. 4 Number of oocytes per ovary (a) and for most developed ovariole (b) of Brontocoris tabidus

(Heteroptera: Pentatomidae) females fed on different diets in field. Columns followed by same letter do not differ for the test of Newman-Keuls $(P=0.05)$
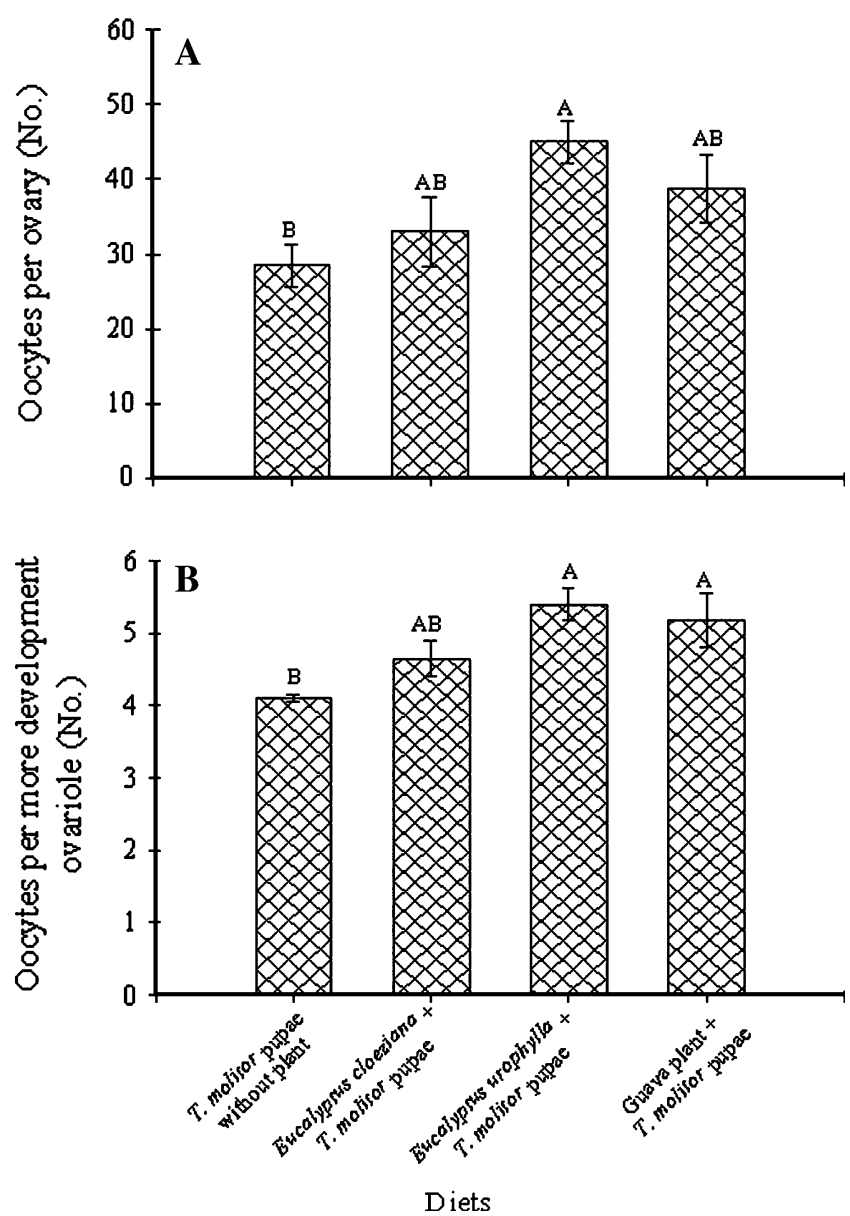


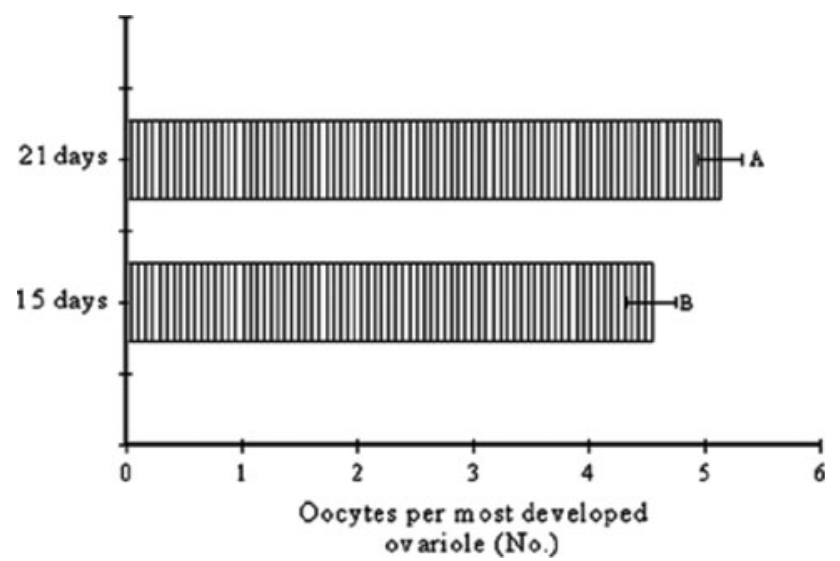

Fig. 5 Number of oocytes per most developed ovariole of Brontocoris tabidus (Heteroptera: Pentatomidae) females in the field in two ages. Columns followed by same letter do not differ by the Student $t$ test $(P=0.05)$

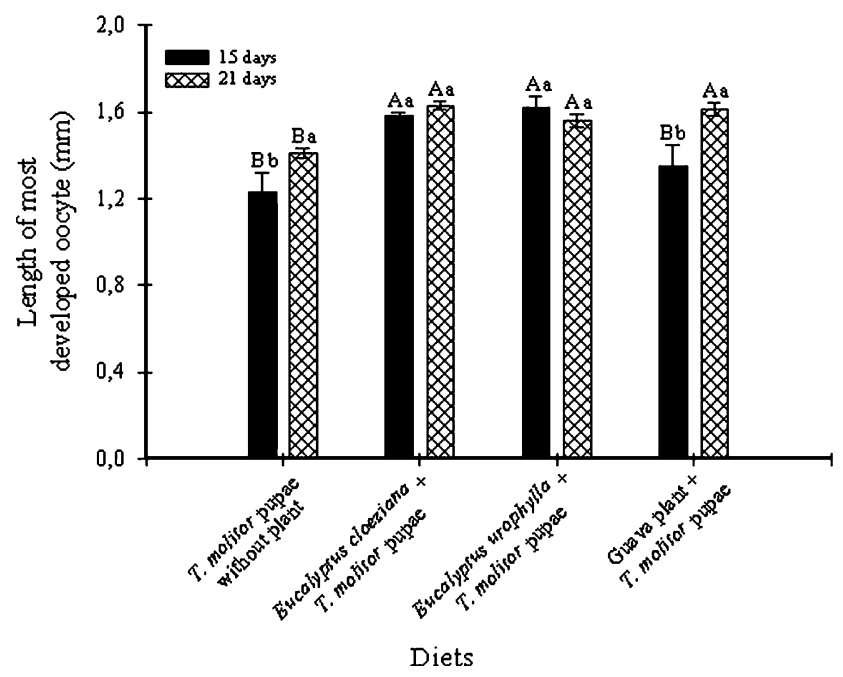

Fig. 6 Length of the most developed oocyte of Brontocoris tabidus (Heteroptera: Pentatomidae) females with 15 or 21 days old in the field. Columns followed by the same capital letter in the diet and small letter in the ages do not differ for the test of Newman-Keuls $(P=0.05)$

feeding and morpho-physiologic aspects of predators. These features are also important for phylogenetic studies of these organisms (Szklarzewicz 1998).

In this study, B. tabidus females fed on prey and plants exhibited more developed ovarioles than those fed on $T$. molitor pupae alone. The number of highly developed ovarioles is directly associated with the number of completely developed oocytes in ovaries of females fed with diets supplied with plants, as shown for $P$. nigrispinus (Lemos et al. 2005a). The size of the ovariole of Pentatomidae is related to the number and degree of development of the follicles (Adams 2001). These observations suggest that, independent of age, B. tabidus females fed on diets containing both prey and eucalyptus or guava plants will have a higher possibility of maximizing their reproductive potential because these diets improve ovarian development.

The number of oocytes per ovary and per most developed ovariole was lower for B. tabidus females fed only on T. molitor pupae, when compared to females fed on both plants and prey. In contrast, P. nigrispinus exhibited a higher number of oocytes per ovary and per ovariole when fed on caterpillars of the cotton leafworm than when fed an artificial diet (Lemos et al. 2005a). This finding may be associated with the higher quantity of fat bodies of insects fed on adequate diet (Lemos et al. 2009).

The ovarioles of B. tabidus females have oocytes of different sizes in all diet conditions. This observation indicates the effect of diet in the development of these structures. Büning (1994) stated that ovarioles contain oocytes in similar developmental stages. However, females of $B$. tabidus fed only on $T$. molitor pupae presented with a smaller number of developed oocytes, resulting in ovarioles with developmental gradients in the same ovary. Similar results were observed in P. nigrispinus females fed on different diets (Lemos et al. 2005a). The ovaries of Musca domestica L. (Diptera: Muscidae) and Drosophila melanogaster Meigen (Diptera: Drosophilidae) halted development in the previtellogenic stage when insects were fed on diets lacking carbohydrates and proteins (Bownes and Reid 1990; Wheeler 1996).

The oocyte size of $B$. tabidus was also affected by the diet, reinforcing the hypothesis that the quantity and quality of the alimentary resources influence oogenesis and synthesis and transport of vitellogenin to the oocytes of Heteroptera (Davey 1997; Wittmeyer et al. 2001). Diets with low nutritional quality may reduce the number of gonadotropic cycles per ovariole by up to $50 \%$ (Adams 2000), as well as the number of vitellogenic follicles of these organisms (Wittmeyer et al. 2001). Therefore, $B$. tabidus females fed only on T. molitor pupae may have a reduced number of gonadotropic cycles and vitellogenic follicles, which would explain the decreased development of their ovaries. Females of B. tabidus fed on prey and plants had larger ovarioles containing higher numbers of well-developed oocytes. In addition, the eggshell and micropyle prolongations developed, demonstrating that the females have completed choriogenesis while on these diets. This observation indicates that the quality and quantity of food eaten during the nymph and adult stages are critical for the reproduction of B. tabidus, as observed for other species of Asopinae (Adams 2000; Wittmeyer et al. 2001; Lemos et al. 2005a).

Brontocoris tabidus does not seem to obtain proteins, the main component of the vitellogenesis and reproduction processes in insects, from plants (Büning 1994; Davey 1997; Wittmeyer et al. 2001; Nation 2002). However, 
feeding on plants may have an indirect benefit, facilitating other metabolic processes (Fialho et al. 2009; Azevedo et al. 2007; Guedes et al. 2007; Sinia et al. 2004). Eating of plants may increase predatory rates, leading to improvements in the development of the reproductive structures of B. tabidus females fed on both prey and plants compared to those fed only on prey.

The reduction in ovarian activation, in the number of developed oocytes, and in the fecundity of B. tabidus fed only on T. molitor pupae may be due to a lack of some nutritional components in the diet. Alternatively, B. tabidus females fed only on prey may eat only to maintain survival, delaying vitellogenesis. Another potential cause of decreased ovarian development and low number of oocytes may be the changes in the endocrine regulation of oogenesis and vitellogenesis. These potential mechanisms demonstrate the necessity of improving knowledge regarding the nutritional and hormonal demands of this predator and the impact of these factors in programs of integrated pest management.

In summary, this study demonstrates that herbivory improves the morphology of the ovary of B. tabidus, affecting the size of the reproductive structures and the oogenesis of this natural enemy in the field.

Acknowledgments We are indebted to the Brazilian research agencies "Conselho Nacional de Desenvolvimento Científico e Tecnológico (CNPq)," "Coordenação de Aperfeiçoamento de Pessoal de Nível Superior (CAPES)," and "Fundação de Amparo à Pesquisa do Estado de Minas Gerais (FAPEMIG)". We are also grateful to the two anonymous experts for their reviews of our manuscript.

\section{References}

Adams TS (2000) Effect of diet and mating status on ovarian development in a predaceous stink bug Perillus bioculatus (Hemiptera: Pentatomidae). Ann Entomol Soc Am 93:529-535

Adams TS (2001) Morphology of the internal reproductive system of the male and female two-spotted stink bug Perillus bioculatus (F.) (Heteroptera: Pentatomidae) and the transfer of products during mating. Invertebr Reprod Dev 39:45-53

Armer CA, Wiedenmann RTN, Bush DR (1998) Plant feeding site selection on soybean by the facultatively phytophagous predator Orius insidiosus. Entomol Exp Appl 86:109-118

Azevedo DO, Zanuncio JC, Zanuncio JS Jr, Martins GF, Silva SM, Sossai MF, Serrão JE (2007) Biochemical and morphological aspects of salivary glands of the predator Brontocoris tabidus (Heteroptera: Pentatomidae). Braz Arch Biol Technol 50:469-477

Bownes M, Reid G (1990) The role of the ovary and nutritional signals in the regulation of fat body yolk protein gene expression in Drosophila melanogaster. J Insect Physiol 36:471-479

Büning J (1994) The insect ovary-ultrastructure, previtellogenic growth and evolution. Chapman Hall, London

Coll M, Ruberson JR (1998) Predatory Heteroptera: an important yet neglected group. In: Coll M, Ruberson JR (eds) Predatory Heteroptera: their ecology and use in biological control. Thomas Say Publications/Entomological Society of America, Lanham, pp 1-19
Davey KG (1997) Hormonal controls of reproduction in female Heteroptera. Arch Insect Biochem Physiol 35:443-453

Eubanks M, Denno RF (1999) The ecological consequences of variation in plants and prey for an omnivorous insect. Ecology 80:1253-1266

Fialho MCQ, Zanuncio JC, Neves CA, Ramalho FS, Serrão JE (2009) Ultrastructure of digestive cells in the midgut of the predator Brontocoris tabidus (Heteroptera: Pentatomidae) after different feeding periods on prey and plants. Ann Entomol Soc Am 102:119-127

Gillespie DR, McGregor RR (2000) The functions of plant feeding in the omnivorous predator Dicyphus hesperus: water places limits on predation. Ecol Entomol 25:380-386

Guedes BAM, Zanuncio JC, Ramalho FS, Serrão JE (2007) Midgut morphology and enzymes of the obligate zoophytophagous stinkbug Brontocoris tabidus (Signoret, 1863) (Heteroptera: Pentatomidae). Pan-Pac Entomol 83:66-74

Jusselino Filho P, Zanuncio JC, Fragoso DB, Serrão JE, Lacerda MC (2003) Biology of Brontocoris tabidus (Heteroptera: Pentatomidae) fed with Musca domestica (Diptera: Muscidae) larvae. Braz J Biol 63:463-468

Lemos WP, Medeiros RS, Ramalho FS, Zanuncio JC (2001) Effects of plant feeding on the development, survival, and reproduction of Podisus nigrispinus (Dallas) (Heteroptera: Pentatomidae). Int J Pest Manage 27:89-93

Lemos WP, Ramalho FS, Serrão JE, Zanuncio JC (2003) Effects of diet on development of Podisus nigrispinus (Dallas) (Het., Pentatomidae), a predator of the cotton leafworm. J Appl Entomol 127:389-395

Lemos WP, Ramalho FS, Serrão JE, Zanuncio JC (2005a) Morphology of female reproductive tract of the predator Podisus nigrispinus (Dallas) (Heteroptera:Pentatomidae) fed on different diets. Braz Arch Biol Technol 48:129-138

Lemos WP, Serrão JE, Ramalho FS, Zanuncio JC, Lacerda MC (2005b) Effect of diet on male reproductive tract of Podisus nigrispinus (Dallas) (Heteroptera: Pentatomidae). Braz J Biol 65:91-96

Lemos WP, Zanuncio JC, Ramalho FS, Serrão JE (2009) Fat body of the zoophytophagous predator Brontocoris trabidus (Het.: Pentatomidae) females: impact of the herbivory. Micron 40:635-638

Lisboa LCO, Serrão JE, Cruz-Landim C, Campos LAO (2005) Effect of larval food amount on ovariole development in queens of Trigona spinipes (Hymenoptera, Apinae). Anat Histol Embryol 34:179-184

Martins GF, Serrão JE (2004) Changes in the reproductive tract of Melipona quadrifasciata anthidioides (Hymenoptera: Apidae: Meliponini) queen after mating. Sociobiology 44:241-254

Matsuda R (1976) Morphology and evolution of the insect abdomen with special reference to developmental patterns and their bearings upon systematics. Pergamon Press, New York

Nation JL (2002) Insect physiology and biochemistry. CRC Press, Boca Raton

Obrycki JJ, Tauber MJ, Tauber CA, Ruberson JR (2004) Prey specialization in insect predators. Available via http://ipmworld. umn.edu/chapters/obrycki.htm. Accessed 01 Nov 2004

Simiczyjew B, Ogorzalek A, Stys P (1998) Heteroptera ovaries: variations on the theme. Folia Histochem Cytobiol 36:147156

Sinia A, Roitberg B, McGregor RR, Gillespie DR (2004) Prey feeding increases water stress in the omnivorous predator Dicyphus hesperus. Entomol Exp Appl 110:243-248

Stefanini M, De Martino C, Zamboni L (1967) Fixation of ejaculated spermatozoa for electron microscopy. Nature 216:173-174

Symondson WOC, Sunderland KD, Greenstone MH (2002) Can generalist predators be effective biocontrol agents? Annu Rev Entomol 47:561-594 
Szklarzewicz T (1998) The ovaries of scale insects (Hemiptera, Coccinea). Morphology and phylogenetic conclusions. Folia Histochem Cytobiol 36:157-165

Wheeler D (1996) The role of nourishment in oogenesis. Annu Rev Entomol 41:407-431

Wittmeyer JL, Coudron TA, Adams TS (2001) Ovarian development, fertility and fecundity in Podisus maculiventris (Say) (Heteroptera: Pentatomidae): an analysis of the impact of nymphal, adult, male and female nutritional source on reproduction. Invertebr Reprod Dev 39:9-20

Zanuncio JC, Alves JB, Zanuncio TV, Garcia JF (1994) Hemipterous predators of eucalypt defoliator caterpillars. For Ecol Manage 65:65-73

Zanuncio JC, Saavedra JLD, Oliveira HN, Degheele D, De Clercq P (1996) Development of the predatory stinkbug Brontocoris tabidus (Signoret) (Heteroptera: Pentatomidae) on different proportions of an artificial diet and pupae of Tenebrio molitor
L. (Coleoptera: Tenebrionidae). Biocontrol Sci Technol 6:619625

Zanuncio JC, Zanuncio TV, Guedes RNC, Ramalho FS (2000) Effect of feeding on three Eucalyptus species on the development of Brontocoris tabidus (Het.: Pentatomidae) fed with Tenebrio molitor (Col.: Tenebrionidae). Biocontrol Sci Technol 10:443450

Zanuncio JC, Lacerda MC, Zanuncio JS Jr, Zanuncio TV, Silva AMC, Espindula MC (2004) Fertility table and rate of population growth of the predator Supputius cincticeps (Heteroptera: Pentatomidae) on one plant of Eucalyptus cloeziana in the field. Ann Appl Biol 144:357-361

Zanuncio JC, Lemos WP, Lacerda MC, Zanuncio TV, Serrão JE, Bauce E (2006) Age-dependent fecundity and fertility life tables of the predator Brontocoris tabidus (Heteroptera: Pentatomidae) under field conditions. J Econ Entomol 99:401-407 